\title{
Strategi Manajemen Brand Ambassador Artis pada Industri Kuliner di Purwokerto
}

\author{
http://dx.doi.org/10.25008/wartaiski.v2i02.38
}

\author{
Ajeng P. Priantana ${ }^{1}$, S. Bekti Istiyanto ${ }^{2}$ \\ ${ }^{1,2}$ Program Magister Ilmu Komunikasi Universitas Jenderal Soedirman \\ J1. Prof. Dr. Boenyamin No. 993, Purwokerto - Indonesia \\ Email korespondensi: ajengpuspita194@gmail.com
}

\begin{abstract}
Abstrak
Tujuan penelitian ini untuk mengetahui bagaimanastrategi manajemen menggunakan Brand Ambassador artis komedian Sule Sutisna berhasil mendorong kemajuan industri kuliner di Purwokerto, Jawa Tengah. Studi menempatkan Rumah Makan "Parte Ceker Rempah" milik Sule sebagai subyek penelitian dan konsumen bersama manajemen rumah makan itu sebagai informan penelitian. Sampel diambil menggunakan purposive sampling, yakni memilih informan yang mengetahui permasalahan. Analisa menggunakan analisis interaktif, meliputi pengumpulan data, reduksi data, penyajian data, dan penarikan kesimpulan. Trend penggunaan Brand Ambassador artis Sule Sutikna dinilai tepat dari sisi pengelolaan manajemen rumah makan. Hasil penelitian dengan menggunakan metode SWOT menyatakan, strategi manajemen reputasi pada industri kuliner menggunakan brand ambassador berhasil menarik minat konsumen untuk berkunjung ke rumah maka "Parte Ceker Rempah" yang berujung pada peningkatan profit usaha setiap bulannya.
\end{abstract}

Kata Kunci: Brand Ambassador, Industri kuliner, Manajemen Reputasi, Komedian, Ceker Rempah

\begin{abstract}
The purpose of this study was to determine how the management strategy using Brand Ambassador comedian artist Sule Sutisna succeeded in encouraging the advancement of the culinary industry in Purwokerto, Central Java. The study places Sule's "Parte Ceker Rumbu" restaurant as a research subject and the consumer together with the restaurant management as a research informant. Samples were taken using purposive sampling, which is selecting informants who know the problem. Analysis uses interactive analysis, including data collection, data reduction, data presentation, and drawing conclusions. The trend of using Brand Ambassador artist Sule Sutikna is judged right in terms of restaurant management. The results of the research using the SWOT method state that the reputation management strategy in the culinary industry using brand ambassadors has succeeded in attracting consumers to visit the home then "Parte Ceker $R$ Spice" which leads to an increase in business profit every month.
\end{abstract}

Keywords: Brand Ambassador, Culinary Industry, Reputation Management, Comedians, Chicken feet spices

\section{PENDAHULUAN}

Industri kuliner merupakan salah satu bidang usaha yang digemari para pengusaha menginat minat masyarakat untuk bersantap di rumah makan tidak pernah surut. Industri kuliner menjanjikan keuntungan berlimpah bila dikelola dengan manajemen yang baik. Hal ini terbukti dari banyaknya produk kuliner di berbagai kota, mulai yang berbentuk booth di food court, warung, cafe, hingga restoran. Masing-masing tempat biasanya menyesuaikan dengan konsep produk yang diusung. Pemilik modal dan produk industri kuliner pun juga berasal dari berbagai golongan, masyarakat kecil, menengah, hingga kalangan atas bahkan para artis tidak sedikit yang menekuni usaha kuliner, seperti Zaskia A. Mecca yang memiliki produk Kue "Mamahke" di Jogja, "Malang Strudel" milik Teuku Wisnu, "Jogja Scrummy" milik Dude Harlino, "Geprek Bensu" milik Ruben Onsu, "Mie Bangcad" milik Arif Muhammad, "Bakmi GM" milik Raffi dan Nagita, serta "Parte Ceker Rempah" milik Komedian Sule.

Para pengusaha kuliner tersebut bersaing satu sama lain untuk memasarkan produk mereka. Salah satu strategi marketing yang efektif dalam menyampaikan promosi dan banyak menarik perhatian adalah menggunakan brand ambassador. Persaingan itu juga sekaligus untuk membangun 
citra usaha, sebab citra dalam sebuah badan usaha merupakan elemen penting untuk kesuksesan sebuah brand (Puspita, 2019).

Penelitian Devi Gita dalam Aulia dan Wardhana (2018) yang menunjukkan, tingkat hubungan antara brand ambassador dengan brand image termasuk dalam katergori yang kuat. Keberadaan merek menjadi salah satu aset berharga yang akan membawa sebuah perusahaan menuju puncak kesuksesan. Kuatnya suatu brand image akan memberikan daya tarik tersendiri bagi para konsumen, sehingga perusahaan akan lebih mudah mendapatkan loyalitas pelanggan. Brand Image juga menjadi kunci bagi para konsumen untuk membedakan produk miliknya dengan milik para pesaing. Brand Image dibentuk dengan membentuk kualitas agar para konsumen tetap percaya dengan produk yang dipasarkan. Dengan produk berkualitas terus menerus berpromosi, akan membuat konsumen semakin tertarik mengkonsumsi produk dengan citra merek yang baik.

Studi ini menyoroti bisnis kuliner milik para artis Indonesia. Bisnis kuliner yang digerakkan oleh artis-artis di Indonesia terdiri dari berbagai jenis produk dan bila bicara soal konsep branding dan reputasi, biasanya produk tersebut lebih cepat dikenal luas oleh masyarakat karena masyarakat mengenal artis tersebut. Konsep branding dengan mengusung nama artis menjadi sebuah strategi branding yang cukup berhasil. Penggunaan endoser, dukungan artis untuk melakukan promosi, disebut dengan brand ambassador, bertujuan untuk menarik konsumen. Pemilihan brand ambassador biasanya didasarkan pada pencitraan seorang selebriti yang terkenal (Royan dalam Putra, 2014:4)

Meski begitu, ada pula artis yang tidak berhasil dalam industri kuliner. Hal ini membuktikan bahwa membranding dan menciptakan reputasi sebuah produk memerlukan manajemen strategis yang harus disesuaikan dengan lingkungan serta kondisi dari produk tersebut. Ada beberapa aspek yang harus dipertimbangkan dalam penyusunan manajemen strategis bisnis kuliner. Pemilihan brand ambassador biasanya didasarkan pada pencitraan melalui seorang selebritis, maka citra merek (brand image) dapat dianggap jenis asosiasi yang muncul dibenak konsumen kerika mengingat sebuah merek tertentu. Keller dalam Devi (2015: 25) menyebutkan, pengukuran citra merek dapat dilakukan berdasarkan pada dimensi merek, yaitu streng of brand association. Favorable old brand association and uniqueness of brand association. Penggunaan brand ambassador merupakan cara yang efektif dalam memperkenalkan suatu produk. Penelitian cenderung menunjukan bahwa penggunaan brand ambassador memiliki efek paing positif. Hal tersebut dipertegas oleh Kotler dalam Dina (2016: 33). Seorang selebriti brand ambassador akan sangat berpengaruh terhadap brand image, suatu produk perusahaan apabila memiliki kredibilitas yang didukung dengan faktor keahlian, sifat dapat dipercaya dan adanya kesukaan. Brand ambassador sangat berperan dalam membantu kelancaran aktivitas pemasaran, baik secara lokal maupun global (Greenwood. 2012: 78).

Berdasarkan latar belakang tersebut, penelitian ini menganalisis aspek-aspek yang dapat mempengaruhi sebuah branding dan reputasi produk dengan penggunaan brand ambassador artis Indonesia. Disini peneliti mengkaji strategi branding Rumah Makan "Parte Ceker Rempah" atau biasa disebut PCR milik komedian Sule Sutisna dengan rumusan masalah: (1) Apa saja kekuatan, kelemahan, kesempatan, dan tantangan PCR; (2) Bagaimana proses Manajemen Reputasi yang dilakukan oleh PCR?

\section{KERANGKA TEORI}

Komunikasi merupakan hal yang sangat penting bagi manusia, karena komunikasi adalah hubungan kontak antar dan antara manusia, baik individu maupun kelompok, karena manusia sejak dilahirkan sudah berkomunikasi dengan lingkungannya. Gerak, tangis bayi saat dilahirkan ke dunia, adalah suatu tanda komunikasi (Widjaja, 2002: 1). Menurut Brelson dan Steiner, komunikasi adalah penyampaian informasi, ide, emosi, keterampilan, melalui penggunaan simbol, angka, grafik (Arifin, 1998: 19 $-25)$.

Menurut Eduard C, Lideman, komunikasi juga termasuk ke dalam hubungan manusiawi, karena mencakup komunikasi antarpersonal (interpersonal communication), untuk membuat orang lain mengerti dan menaruh simpati, karena orang akan menaruh simpati jika dirinya di hargai. Model komunikasi menggambarkan bagaimana jalannya proses komunikasi yang mengalir melalui saluran komunikasi dari sender, kepada receiver (Wibowo, 2013: 167). Komunikasi dalam hubungan 
e-ISSN: 2686-0724 - p-ISSN: 0853-4470 - Vol. 02, No. 02 (2019), pp. 131-139 masyarakat digunakan secara luas, oleh departemen, jawatan, perusahaan, badan, lembaga (Effendy, 2013: 131).

Menurut Lea Greenwood indikator Brand Ambassador terdiri dari (1) Transference (Pemindahan), adalah ketika seorang selebritas mendukung sebuah merek yang terkait dengan profesi mereka; (2) Congruence (Kesesuaian), merupakan konsep kunci pada brand ambassador, yakni memastikan ada kecocokan antara merek dan selebritis; (3) Kredibilitas, konsumen melihat suatu sumber ambassador memiliki pengetahuan keahlian atau pengalaman yang relevan dan sumber tersebut dapat dipercaya untuk memberikan suatu informasi yang objektif; (4) Daya Tarik, merupakan tampilan non-fisik yang menarik yang dapat menunjang suatu produk maupun iklan; (5) Power, merupakan kekuatan atau kharisma yang dipancarkan oleh narasumber untuk dapat memegaruhi konsumen sehingga konsumen membeli produk tersebut (Lea Greenwood, 2012: 77).

\section{METODE PENELITIAN}

Penelitian ini adalah penelitian kualitatif. Menurut Keirl dan Miller (Moleong, 2012: 2) metode kualitatif merupakan penelitian yang menekankan pada proses dan makna yang tidak dikaji secara ketat atau belum diukur serta sifat realita yang terbangun secara sosial, hubungan erat antara peneliti dengan subjek yang diteliti. Penelitian fokus pada trend penggunaan brand ambassador artis pada industri kuliner Indonesia.

Pengambilan sampel menggunakan purposive sampling dengan pemilik outlet dan konsumen yang berada di outlet ditetapkan sebagai informan. Teknik pengumpulan data dilakukan melalui dokumentasi dan wawancara pemilik outlet dan para konsumen. Sedangkan analisa yang digunakan adalah analisis interaktif, meliputi pengumpulan data melalui pengamatan langsung ke lokasi penelitian, melakukan wawancara dan mendokumentasikan, kemudian mereduksi data sebelum dianalisis dalam penyajian data untuk kemudian hasilnya dapat disimpulkan.

\section{HASIL PENELITIAN}

Bisnis kuliner dalam bentuk rumah makan dengan nama "Parte Ceker Rempah" di Purwokerto, Jawa Tengah, pada awalnya merupakan warung kecil dengan nama berbeda. Warung tersebut masih terletak di area Purwokerto. Pemiliknya, ingin mengembangkan usahanya itu dengan cara menggandeng brand ambassador untuk mengangkat produk penjualan, sehingga dibentuk sebuah brand baru dengan nama "Parte Ceker Rempah". Sesuai namanya, produk yang ditonjolkan adalah ceker ayam yang dipadukan kuah rempah. Meskipun, terdapat menu lain, namun menu ceker menjadi menu andalan.

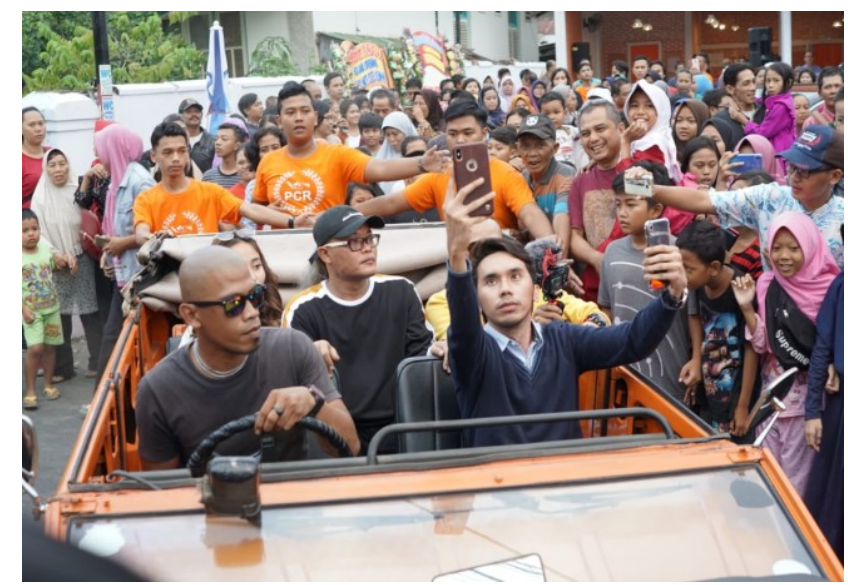

Gambar 1. Antusias masyarakat menyambut Brand Ambassador Sule

Dengan penggunaan brand ambassador Sule Sutisna maka produk makanan yang ditawarkan diharapkan bisa meningkatkan omset penjualan, karena komedian Sule telah dikenal masyarakat luas. Sule adalah pelawak yang sering tampil di televisi, sehingga brand ambassador ini menjadi kekuatan untuk menarik pembeli. Selain rasa menu ceker yang enak dan unik, brand ambassador Sule membuat banyak konsumen semakin tertarik dengan menu ceker ini. PCR juga memberikan konsep yang 
e-ISSN: 2686-0724 - p-ISSN: 0853-4470 - Vol. 02, No. 02 (2019), pp. 131-139 berbeda dari restoran pada umumnya, karena konsep unik yang dicetuskan yakni menggunakan konsep politik. Hal tersebut terlihat dari nama restoran itu sendiri "Parte Ceker Rempah" yang mengusung kata "Parte" yang merujuk pada kata "partai politik. Pemilihan nama itu berkaitan dengan kondisi politik di bulan April yang tengah berada dalam pusaran pelaksanaan Pemilihan Umum Presiden.

Tidak hanya soal nama, pelayanan pun dikonsepkan seperti sedang melakukan pemungutan suara dengan cara mencoblos menu makanan pada surat suara di dalam bilik suara. Daftar menu juga unik, menghadirkan klasifikasi level pedas, "parpol” (parah pol) hingga menu ceker tidak pedas, dinamakan "Golput". Outlet pertama PCR berlokasi di Tebet, Jakarta Selatan. Setelah melihat pertumbuhan yang cukup bagus, dibuka cabang di Purwokerto, karena si pemilik brand merupakan orang asli Purwokerto. Cabangnya terletak di Jl. H.R Bunyamin, dengan penyebutan nama meniru gaya pengorganisasian partai politik, yakni "Dewan Perwakilan Cabang" (DPC). Sang owner kembali membuka outlet ketiga dengan istilah "Perwakilan Anak Cabang" (PAC) di daerah Kranji Purwokerto.

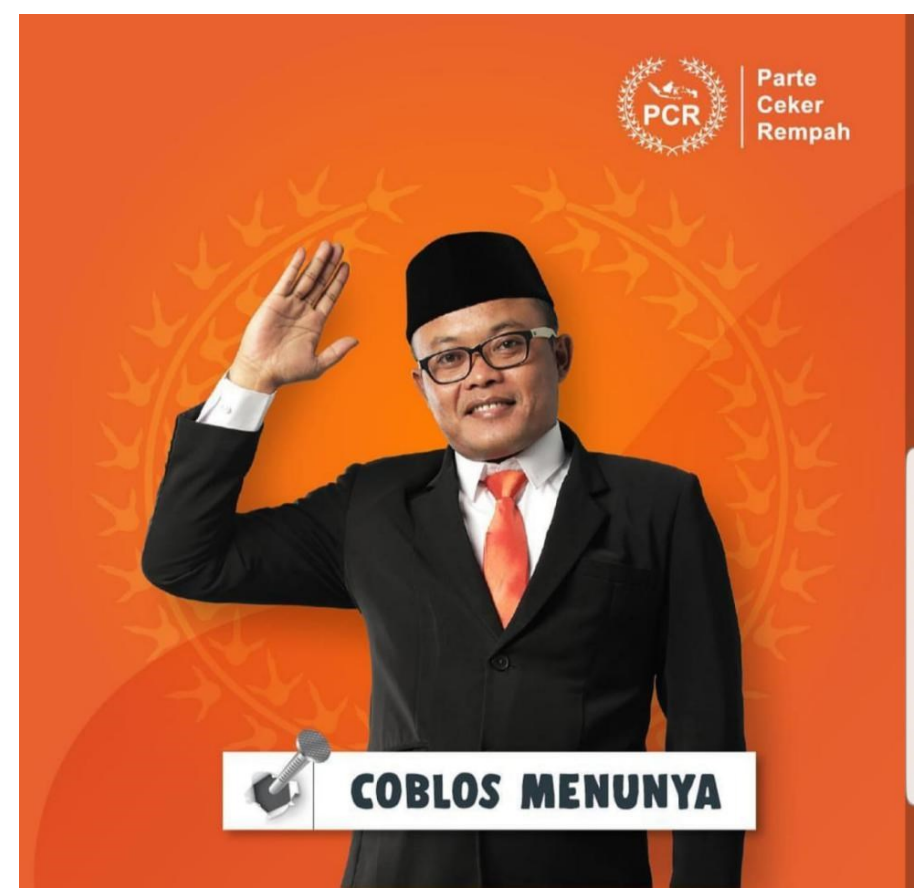

Gambar 2. Komedian Sule dalam daftar menu PCR

Pembahasan dalam studi ini menggunakan pendekan SWOT. Menurut Philip Kotler, analisis swot adalah evaluasi terhadap semua kekuatan, kelemahan, peluang, dan ancaman yang terdapat pada individu atau organisasi. Terdapat unsur-unsur analisis SWOT, SWOT merupakan sebuah metode yang digunakan untuk membuat evaluasi kekuatan, kelemahan, peluang dan ancaman dalam bisnis. SWOT melibatkan empat unsur, yaitu Strength (kekuatan), Weakness (kelemahan), Opportunity (peluang) dan Threaths (ancaman). Berikut penjelasan dari masing-masing unsur tersebut (tabel 1):

Tabel 1. Analisis SWOT pada RM Parte Ceker Rempah

\begin{tabular}{|c|c|c|}
\hline Faktor Internal /Faktor Eksternal & (S) Strengths (Kekuatan) & (W) Weakness (Kelemahan) \\
\hline (O) Opportunities (Kesempatan) & $\begin{array}{l}\text { Strategi SO: } \\
\text { Memanfaatkan seluruh kekuatan untuk } \\
\text { merebut dan memanfaatkan peluang } \\
\text { sebesar-besarnya dengan strategi } \\
\text { menggunakan Brand Ambassador Sule } \\
\text { sebagai kekuatan untuk menarik } \\
\text { pelanggan. }\end{array}$ & $\begin{array}{l}\text { Strategi WO: } \\
\text { Strategi yang ditetapkan berdasarkan } \\
\text { pemanfaatan peluang yang ada dengan } \\
\text { cara meminimalkan kelemahan yang } \\
\text { ada, seperti kurangnya stok ceker yang } \\
\text { tersedia, dikarenakan banyaknya } \\
\text { permintaan pembeli, sehingga outlet } \\
\text { PCR tersebut menyediakan menu- } \\
\text { menu lain selain ceker. }\end{array}$ \\
\hline (T) Threat (Ancaman) & \begin{tabular}{l}
\multicolumn{3}{c}{ Strategi ST: } \\
Strategi yang diterapkan berdasarkan \\
kekuatan yang dimiliki organisasi
\end{tabular} & $\begin{array}{l}\text { Strategi TW: } \\
\text { Strategi yang diterapkan berdasarkan } \\
\text { kegiatan yang bersifat defensif dan }\end{array}$ \\
\hline
\end{tabular}




\begin{tabular}{|l|l|l|}
\hline & $\begin{array}{l}\text { untuk mengatasi ancaman, seperti } \\
\text { outlet PCR berencana membuka } \\
\text { cabang yang lebih banya, supaya } \\
\text { produk PCR semakin kuat di } \\
\text { masyarakat dan juga untuk } \\
\text { mengantisipasi pedagang lain yang } \\
\text { ingin meniru produk PCR. }\end{array}$ & $\begin{array}{l}\text { Terdapat pesaing PCR yang sama } \\
\text { menyediakan menu ceker, seperti pada } \\
\text { outlet yang bernama DXWR yang } \\
\text { lokasinya tidak jauh dari outlet PCR. } \\
\text { Perbedaanya outlet DXWR tidak } \\
\text { menggunakan Brand Ambassador dan } \\
\text { menggunakan konsep biasa saja, } \\
\text { berbeda dengan produk PCR yang } \\
\text { menggunakan Brand Ambassador dan } \\
\text { menggunakan konsep yang berbeda } \\
\text { dengan outlet-outlet pada umumnya, } \\
\text { seperti pemesanan sampai tahap akhir } \\
\text { pembayaran menggunakan konsep } \\
\text { seperti pemilihan umum. }\end{array}$ \\
\hline
\end{tabular}

\section{Strengthness (Kekuatan)}

Analisis terhadap unsur kekuatan yang dimiliki outlet PCR, adalah menganalisis tentang kelebihan apa saja yang dimiliki outlet PCR. Hal tersebut dapat dilihat dalam segi teknologi, kualitas hasil produksi, lokasi strategi atau unsur pada keunggulan outlet yang membuat sebanyak mungkin daftar kekuatan sebagai upaya memenangi kompetisi. Misalnya dengan menggunakan Brand Ambassador, menampilkan konsep menu yang berbeda untuk menarik para pelanggan, telah menjadi fokus utama dari manajemen ini. Teknologi yang digunakan pun tergolong maju karena mesin kasir tidak menggunakan layar komputer yang besar hanya berupa tablet saja. Kualitas produksi juga baik, memiliki keunggulan dan keunikan. Lokasi yang sangat strategis juga menjadi salah satu daya tarik bagi pengunjung untuk mampir ke outlet tersebut.

\section{Weakness (Kelemahan)}

Untuk mengetahui kelemahan yang dimiliki outlet PCR dilakukan pembandingan dengan outlet sejenis. Dengan membuat daftar kelemahan outlet PCR secara obyektif bisa diperoleh melalui testimony konsumen yang lebih mengetahui kekurangan dari menu PCR. Kelemahan outlet PCR ini adalah berupa kurangnya stok bahan utamanya, yaitu ceker. Ketika permintaan sangat tinggi, manajemen harus menutup outlet dan menolak pelanggan karena kehabisan bahan baku.

\section{Opportunities (Peluang)}

Peluang bisnis kuliner ini diperoleh dari adanya produk yang dapat diterima oleh masyarakat, kemudian memiliki konsep unik berbeda dari yang lain dan memiliki brand ambassador. Kelebihan-kelebihan tersebut dapat dimanfaatkan untuk peluang pada bisnis kuliner sektor lain. Hal ini terbukti dari penuturan manajemen bahwa mereka berniat membuka bisnis kuliner dengan jenis yang berbeda namun tetap dengan brand ambassador yang sama, namanya Bakso Sunami (Sule dan Naomi yang merupakan nama kekasih Sule).

\section{4. $\quad$ Threat (Ancaman)}

Berbicara mengenai tantangan, berdasarkan penuturan manajemen adalah peniruan produk serupa yang menjadi pesain, misalnya terdapat outlet yang bernama DXDR, tidak jauh dari outlet PCR yang juga menyediakan menu ceker seperti pada produk PCR. Maka dari itu jalan yang ditempuh manajemen adalah terus mengembangkan outlet ini di berbagai kota di Indonesia. 


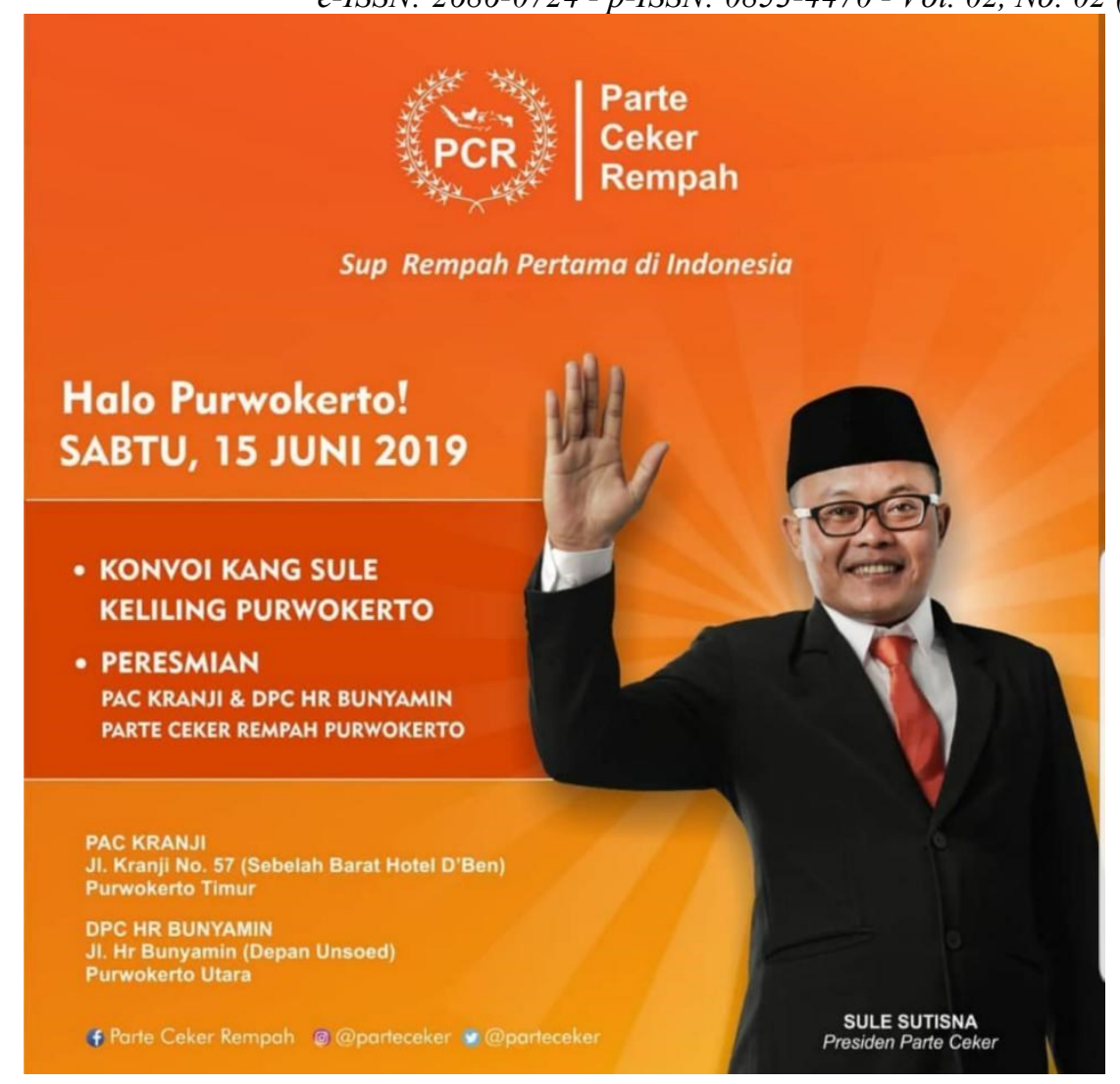

Gambar 3. Inovasi PCR dengan brand ambassasor Sule

Emotional Appeal. Kepercayaan masyarakat terhadap produk PCR tumbuh karena cita rasa masakannya yang enak serta unik, dari cara pemesanan sampai pembayaran. Juga karena adanya brand ambassador Sule yang menjadi daya tarik outlet. Selain itu, pemilihan warna ikon produk juga memiliki arti. Manajemen memutuskan menggunakan warna oranye dengan pertimbangan belum ada partai politik yang memakai warna ini. Selain itu, secara filosofis warna oranye juga merupakan warna yang dapat menarik selera makan pengunjung. Harapannya, orang yang makan di PCR juga menikmati semua produk dan suasananya.

Product and Service (Produk dan Pelayanan). Outlet PCR menyediakan produk unggulan berupa ceker yang dipadukan dengan kuah yang kaya akan rempah-rempah. Makanan disajikan dengan pelayanan menggunakan tema politik, suatu yang tidak dijumpai pada outlet industri makanan sejenis.

Vision and Leadership (Visi dan Kepemimpinan). Untuk bisnis, "Parte Ceker Rempah" memiliki visi Menjadi pilihan utama para pecinta ceker dan kuliner khas Nusantara dengan bumbu rempah-rempah warisan bangsa Indonesia yang memiliki karakter rasa kuat. Adapun misi rumah makan itu adalah menyajikan menu olahan khas Nusantara dengan aneka bumbu rempah yang rasanya kuat serta menghadirkan suasana baru dalam menikmati hidangan dengan suasana pemilu dan demokrasi.

Workplace Environment (Tempat dan Lingkungan Perusahaan). Outlet PCR yang diteliti bertempat di Purwokerto di Jl. HR. Bunyamin. Berdasarkan pengamatan, outlet ini menjadi salah satu tempat favorit untuk nongkrong karena tempatnya yang luas dan dilengkapi fasilitas wifi yang kencang, membuat banyak mahassiswa betah di sana. Selain itu, dilengkapi juga dengan smoking area, sehingga menjadi tempat favorit.

Financial Performance (Kinerja Keuangan). Berdasarkan penuturan manajemen, profit merupakan hal yang dinamis, namun secara keseluruhan profitnya yang didapat cenderung meningkat dari awal dibukannya restoran hingga kini. Hal ini menandakan antusiasme masyarakat akan produk ini.

Social Responsibility (Tanggung Jawab Sosial). Outlet ini menjalankan tanggung jawab sosial dengan memberi bantuan dan santunan ke rumah sakit sebanyak 80 box per-minggu. Bantuan 
itu merupakan rasa peduli manajemen terhadap mereka yang membutuhkan bantuan. Selain itu, manajemen juga sering membagikan nasi bungkus ke masjid sekitar.

Inovation (Inovasi). Inovasi dilakukan dengan membuka PCR di Kranji dengan konsep sedikit berbeda dengan PCR di Jalan HR Bunyamin, yaitu dengan menambahkan kedai kopi 24jam, mengusung konsep vintage. Untuk inovasi jangka panjang, dihadirkan menu tambahan berupa bakso yang diberi nama "Sunami", singkatan dari Sule dan Naomi (kekasih Sule).

\section{KESIMPULAN}

Kesimpulan penelitian ini adalah penggunaan brand ambassador artis Indonesia menjadi hal yang cukup siginifikan dalam brand awareness. Strategi manajemen reputasi pada industri kuliner dengan menggunakan brand ambassador berhasil menarik minat konsumen untuk berkunjung ke rumah makan "Parte Ceker Rempah" yang berujung pada peningkatan profit usaha setiap bulannya.

Diperlukan sebuah kematangan dalam menganalisa peluang, ancaman, kekuatan, sserta kelemahan dalam sebuah produk untuk membantu pemilik agar terus bisa berinovasi dalam mengambangkan produknya sehingga tidak berhenti di tengah jalan. Selain itu, adanya pengelolaan manajemen reputasi yang baik, terstruktur, sistematis, dan tepat akan dapat sangat membantu brand untuk menciptakan citra positif di masyarakat. Hal ini harus dilakukan dengan mengusung brand ambassador yang dikenal oleh masyarakat luas.

\section{DAFTAR PUSTAKA}

Abdilah, Suharyono, Putra I. 2014. Pengaruh Brand Ambassador terhadap Brand Image serta Dampaknya terhadap Keputusan Pembelian (Survey pada Penggunaan LINE di Asia). Jurnal Administrasi Bisnis, Vol 12(1): 1-10.

Arifin, Anwar. 1988. Ilmu Komunikasi Sebuah Pengantar Ringkas. Jakarta: Raja Grafindo Persada.

Aulia dan Wardhana. 2018. Pengaruh Brand Ambassador terhadap Brand Image pada Mamahke Jogja. e-Proceeding of Management. Vol.5 (2): 2569.

Effendy, Onong Uchjana. 2006. Hubungan Masayarakat: Suatu Studi Komunikasi. Bandung: Remaja Rosdakarya.

Gita, Devi. 2016. Pengaruh Brand Ambassador terhadap Brand Image Loreal Paris.

Kotler, Philip dan Keller, Kelen. 2012. Manajemen Pemasaran. Erlangga: Jakarta.

Kotler, Philip \& Armstrong, Gary. 2012. Principle of Marketing. New Jersey: Pearson.

Lea-Greenwood, Gaynor. 2012. Fashion Marketing Communications, E-book. Somerset, NJ, USA: Wiley.

Moleong. J. Lexy. 2016. Metodologi Penelitian Kualitatif. Bandung; Remaja Rosdakarya

Patilima, Hamid. 2013. Metode Penelitian Kualitatif. Bandung: Alfabeta.

Puspita, Irene Melia. 2019. Marketing Public Relation Peremajaan Merek sebagai Strategi Pemasaran dalam Membangun Citra Produk Baru, Warta Ikatan Sarjana Komunikasi Indonesia, Vol. 2(1): 19-26. 